\title{
Characteristics of Self-efficacy in the Space of an Individual's Self-determination
}

\section{Характеристика самоефективності у просторі самодетермінації особистості}

\author{
Mariia Dryhus \\ Ph.D. in Psychology, \\ Senior Researcher of \\ the Chamata Laboratory of \\ Psychology of Personality
}

\author{
Марія Дригус \\ кандидат психологічних наук, \\ старший науковий співробітник \\ лабораторії психології \\ особистості імені П. Р. Чамати
}

E-mail: mariatrd33@gmail.com orcid.org/0000-0003-0648-0183

Researcher ID: G-4671-2018
G. S. Kostiuk Institute
of Psychology of NAES
of Ukraine, Kyiv, Ukraine
2, Pankivska street,
Kyiv, 01033

Інститут психологї̈ ілені Г. С. Костюка НАПН України, л. Київ, Украӥна вул. Паньківська, 2, м. Київ, 01033

Original manuscript received April 04, 2019 Revised manuscript accepted April 26, 2019

\section{ABSTRACT}

The results of the theoretical and experimental research on self-efficacy in the space of an individual's self-determination are presented in the article. The concept of self-efficacy is analyzed theoretically and methodologically from the point of view of different conceptual approaches of national and foreign psychology. A. Bandura's conceptual paradigm of self-efficiency is discussed in the context of reciprocal determinism of self-efficacy within the social learning theory. G. S. Kostiuk's conceptual paradigm concerning formation of an individual's efficacy is revealed within the concept of mental development. 
The fact is emphasized that G. S. Kostiuk initially and originally put forward the problem of personal self-efficacy within the systemic approach in the 40ies of the 20th century. The conceptual foundations for development of the "self-efficacy" issue in the national psychology are presented, as well as experimental studies on an individual's self-determination in the contemporary national psychological space. The experimental research on interconnections in the "self-efficiency - self-determination" system is analyzed. Self-efficacy in the field of life-meaningful orientations is characterized and relations of self-efficacy with the plane of an individual's self-determination are observed; interrelations in the "self-efficacy - hardiness" opposition are determined; interconnections of self-efficacy and self-determination are established. The tendencies of interconnections in the dichotomous "self-efficacy - self-determination" system are determined. The model of productive self-efficacy on the plane of an individual's self-determination is outlined. The dominant features that are the most important for the formation of interconnections in the "self-efficacy-self-determination" system are identified.

Key words: personality, self-efficacy, self-determination, development, psychological hardiness, life-meaningful orientations, self-attitude.

\section{Вступ}

Сучасні трансформаційні суспільні процеси ставлять у ранг пріоритетної проблему становлення особистості, здатної бути ефективною у різноманітних спектрах її включення у системи «Я - світ», «Я - Я», а також «Я - суб’єкт навчальної та професійної діяльності». Саме становлення продуктивної самоефективності є однією з ключових проблем екологічного розвитку особистості у цих системах. Значущість цієї проблеми зростає у контексті «нової концепції студентоцентрованого навчання». Відомий вітчизняний учений, національний експерт у галузі освітньої політики та реформування вищої освіти в Україні Т. В. Фініков, розкриваючи сенсотвірні спектри «студентоцентрованої моделі освіти», наголошує на необхідності «отримання кожним випускником закладу вищої освіти: широких знань, які забезпечують можливість швидкої адаптації до змін у суспільстві й економіці; добрих базових умінь і компетентностей, що стимулюють прагнення до постійного 
навчання; належних умінь учитися, розвиненого організаційного мислення, які дають змогу з успіхом діяти в умовах невизначеності, поліваріативності рішень, відсутності повної інформації; достатнього досвіду у використанні знань і компетентностей для вирішення незнайомих проблем і завдань» (Фініков, 2018: 51).

Досягнення цих цілей вимагає домінантної уваги до проблеми розвитку особистісної ефективності у студентської молоді. Тому онто- й актуалгенеза самоефективності у концептуальному полі самодетермінації особистості набувають особливого статусу як у теоретико-методологічній, так і експериментально-технологічній площинах.

У сучасному вітчизняному науковому просторі аналіз проблеми самодетермінації особистості висвітлено у таких спектрах: здійснено теоретико-методологічний аналіз самодетермінації особистості, а також її психологічних чинників (Сердюк, 2018); установлено можливості впливу життєвих перспектив на активізацію самодетермінації розвитку особистості у кризових ситуаціях (Володарська, 2018); з'ясовано ціннісні аспекти самореалізації особистості у контексті самодетермінації (Пенькова, 2018); розкрито проблему самодетермінації особистості в часі (Турбан, 2018); здійснено аналіз особистісної автономії як ключової ознаки самодетермінації особистості (Чайка, 2017); висвітлено особливості прояву компонентів життєстійкості особистості (Чиханцова, 2018); охарактеризовано проблему самоставлення та смисложиттєвих орієнтацій студентської молоді у процесі самодетермінації особистісного розвитку (Яворська-Вєтрова, 2018).

Зауважимо, що проблема самоефективності особистості є предметом підвищеної уваги вітчизняних науковців у різних галузях психологічного знання. Зокрема, у новітніх теоретико-експериментальних дослідженнях здійснено системний аналіз проблеми самоефективності керівників освітніх організацій: 3'ясовано організаційно-професійні та гендерні її особливості; розкрито роль самоефективнос- 
ті менеджерів організацій як внутрішньої детермінанти розвитку організаційної культури освітніх організацій (Бондарчук, 2015); експериментально досліджено детермінацію та особливості самоефективності педагогічних працівників загальноосвітніх навчальних закладів (Мушегов, 2016); проведено аналіз проблеми розвитку творчої самоефективності особистості студентської молоді (Фалькова, 2017); здійснено теоретико-методологічний аналіз образу «Я-професіонал» як складової «Я-концепції» особистості, а також емоційно-ціннісного ставлення до себе як до ефективного суб'єкта майбутньої професійної діяльності (Онуфрієва, 2018). Уперше здійснено теоретико-методологічний аналіз концепції психічного розвитку Г. С. Костюка у парадигмі особистісної ефективності (Дригус, 2016).

Прикметно, що у теорії самодетермінації Е. Десі та Р. Райана, яка розроблена у середині 80-х років ХХ ст., самоефективність розглядається у контексті базальних потреб, що складають підгрунтя внутрішньої мотивації. Вирізняються такі три потреби: потреба у самодетермінації, потреба у компетентності та потреба у зв'язках з іншими. Самоефективність складає сенсове поле потреби у компетентності. За Е. Десі та Р. Райаном, потреба у компетентності - це потреба відчувати власну ефективність, за якою людина діє і при цьому розуміє, що вона правильно діє. Причому, серед трьох базальних потреб у часовому континуумі першою має задовольнятися потреба у компетентності, за якої людина переживає почуття компетентності (Deci \& Ryan, 2000).

Зазначимо, що самоефективність є одним із ключових чинників у системі самодетермінації особистості, їі здатності бути ефективним суб'єктом власного життєвого простору, професійної та учіннєвої діяльності, а також самопроектування й творення власного «Я», здатного до успішного саморозвитку та самореалізації (Максименко \& Сердюк, 2016). 
Мета статті - здійснити аналіз теоретико-експериментального дослідження проблеми самоефективності у просторі самодетермінації особистості.

\section{Завдання статті}

1. Здійснити теоретико-методологічний аналіз проблеми самоефективності у різних концептуальних парадигmax.

2. Дати характеристику взаємозв'язків у системі «самоефективність - самодетермінація» особистості.

\section{Методи та методики дослідження}

У процесі дослідження було застосовано: теоретикометодологічний аналіз проблеми самоефективності та самодетермінації; методики дослідження: тест «Смисложиттєві орієнтації» Дж. Крамбо та Л. Махоліка (Леонтьєв, 2000), тест «Шкала самодетермінації» К. Шелтона (Осін, 2007), тест «Шкала самоефективності» Р. Шварцера та М. Єрусалема (Ромек, 1996), тест життєстійкості С. Мадді (Леонтьєв \& Розсказова, 2006), тест-опитувальник «Самоставлення особистості» В. В. Століна та С. Р. Пантілєєва (Столін \& Пантілєєв, 1988).

У дослідженні взяли участь 235 студентів закладів вищої освіти. Статистична обробка даних здійснена за допомогою комп’ютерної програми SPSS Statistics 21.0.

\section{Результати та дискусії}

Перший спектр нашого розгляду включає аналіз концептуальної парадигми самоефективності особистості Альберта Бандури, який увів цей концепт у психологічний простір. «Самоефективність - термін Альберта Бандури для визначення відчуття індивідом своїх здібностей, своїх можливостей оволодіти певним набором ситуацій, які виникають у його житті» - таке визначення має концепт «самоефективність» у Великому тлумачному психологічному словнику Артура Ребера, який є «одним із найавторитетні- 
ших і широко використовуваних словників» (Ребер, 2000: 221).

Ефективність поведінки людини описана Бандурою у концептуальному баченні самоефективності (особистісної ефективності), її джерел, витоків та особливостей перебігу залежно від реципрокної інтерактивності (Bandura, 1978). Прикметно, що джерела самоефективності учений розкриває у концепції реципрокного детермінізму як складової його теорії соціального научіння (Bandura, 1977). Основоположною є теза, що людська поведінка зумовлюється складною безперервною взаємодією зовнішніх і внутрішніх чинників, які є взаємозалежними детермінантами.

«Теорія соціального научіння, - наголошує А. Бандура, - підходить до пояснення людської поведінки у термінах неперервної реципрокної інтерактивності між когнітивними, поведінковими і зовнішніми детермінантами. Можливості людей здійснювати вплив на свою долю, а також їх самоуправління обмежені рамками процесу реципрокного детермінізму. Така концепція людського функціонування, з одного боку, не робить людину безсилою істотою, яка кинута напризволяще зовнішніх сил; з іншого боку, не уявляє її і абсолютно вільним фізичним агентом, здатним стати ким завгодно. Людина та їі оточення є взаємовпливовими детермінантами» (Бандура, 2000: 9-10). Учений аналізує детермінантну роль середовища, вирізняючи в ній «потенційне зовнішне середовище» $\mathrm{i}$ «актуальне зовнішнє середовище». Він розкриває методологію процесу реципрокної взаємодії між особистісним, персональним впливом і впливом оточуючого середовища.

Розкриваючи питання взаємозалежності особистісних чинників і впливу оточення, А. Бандура дає таке визначення особистісної детермінації: «Вплив, викликаний індивідуумом, а також його чи її поведінкою, визначатимемо як особистісну детермінанту» (Бандура, 2000: 266). Він звертає увагу на те, що «особистісні детермінанти лише потен- 
ційні, які не виявляють себе, якщо не будуть реалізовані» (Бандура, 2000: 266).

Концептуально важливим у розумінні самоефективності є розмежування таких спектрів, як «очікування ефективності» й «очікування результату» в континуумі «особистість - поведінка - результат». Очікування результату визначається «як особистісна оцінка того, що та чи інша поведінка повинна призвести до тих або інших результатів» (Бандура, 2000: 115). Очікування ефективності $є$ «переконанням у тому, що індивід здатний успішно здійснити поведінку, необхідну для досягнення очікуваних результатів» (Бандура, 2000: 115-116). Концепт «власної ефективності» Бандура розглядає в оцінковій проекції, причому це повинна бути «висока оцінка особистісної ефективності» (Бандура, 2000: 116). Роль цієї високої оцінки має двоїстий зміст. 3 одного боку, вона «знижує прогностичні страхи і гальмування», а з іншого - здійснює вплив на ті зусилля і спроби особистості, які вона здійснює завдяки «передбаченню майбутнього успіху» (Бандура, 2000: 116).

Учений чітко описує континуум того змісту, що окреслює розуміння концепту «очікування ефективності» у детермінантній проекції. «Очікування ефективності, - зазначає А. Бандура, - визначає, скільки зусиль докладе індивід, як довго він зможе протистояти перешкодам, витримувати ворожі обставини і неприємні переживання» (Бандура, 2000: 116).

Тобто, очікування ефективності детермінує спектр зусиль - моно- чи полі- - їх множинність, часову тривалість власної стійкості. А. Бандура вказує на лінійність зв'язку між ступенем очікування й особистісною активністю: «чим вище очікування ефективності чи майстерності, тим активнішими стають зусилля» (Бандура, 2000: 116). При цьому важлива роль саморегуляції (якій учений приділяє значну увагу в своїй теорії), наявності її певних якостей, а саме - наполегливості у подоланні перешкод, яка не лише «зміцнює почуття власної ефективності» (ще один кон- 
цепт, уведений А. Бандурою), але й благотворно впливає на «зняття» деструкції як емоційної сфери, так і поведінкової.

У теорії соціального научіння А. Бандура системно розглядає широку палітру «само-»: самоповагу, самоуправління, самооцінкові системи, самосприйняття, самомотивацію, самоініціативу, почуття самозадоволення тощо. Прикметно, що має місце аналіз у дихотомічній проекції, наприклад, негативне самосприйняття - позитивне самосприйняття, самозадоволення - самонезадоволення. Така осяжність розгляду проблеми дає змогу чітко окреслити стратегії становлення і розвитку самоефективної особистості. Зауважимо, що концепт «самоефективність», уведений А. Бандурою і широко вживаний і нині, у розгорнутій теорії соціального научіння має дещо іншу модифікацію. Так, учений вживає такі поняття, як «особистісна ефективність», «сила впевненості людини у власній ефективності», «почуття ефективності», «почуття особистісної ефективності» .

Концепція самоефективності А. Бандури є продуктивною й у XXI ст. (Бандура, 2018, 2012). Зважаючи на масштабність і багатогранність спектрів експериментальних досліджень проблеми самоефективності, їх аналіз вимагає окремого розгляду.

Наступний спектр - характеристика концептуальних ідей Г. С. Костюка щодо проблеми становлення ефективної особистості. Зазначимо, що проблема особистісної ефективності у концептуальному підході А. Бандури розкрита у контексті загальної та соціальної психології. Але акцентуємо увагу на тому, що проблему ефективності особистості у системному вимірі Г. С. Костюк уперше самобутньо ініціював у педагогічній та віковій психології (як у вітчизняній, так і зарубіжній) (Костюк, 1941, 1989). Саме він створив концепцію ефективності в різних системах життєдіяльності дитини в освітньому просторі. Учений актуалізував проблему ефективного особистісного становлення школя-

(C) Mariia Dryhus 
ра, означивши її у сенсовому полі як створення умов для особистості «зростати власними силами» .

Окреслимо загальну архітектоніку концептуальних ідей Г. С. Костюка. Проблему становлення ефективної особистості Г. С. Костюк розкрив у контексті концепції психічного розвитку індивіда зі стрижневою ідеєю саморозвитку та саморуху особистості. У ній висвітлено стрижневі проблеми детермінації психічного розвитку, в яких проектуються засадничі ідеї становлення особистісної ефективності; розкрито роль середовища - природного, предметного та суспільного, а також внутрішніх умов психічного розвитку в становленні ефективної особистості; з'ясовано статус ідеї саморозвитку та саморуху особистості, ідеї керування особистістю власним психічним розвитком у парадигмі особистісної ефективності; охарактеризовано індивіда як активного діяльнісного суб'єкта власного саморозвитку, що є підгрунтям становлення особистісної ефективності (Костюк, 1941, 1989). Висунута ідея «прогресивного психічного саморуху» як вектор змін «внутрішнього, особистого»- це унікальна антиципація Г. С. Костюком сенсу особистісної ефективності.

Концептуальний аналіз проблеми детермінації психічного розвитку, самобутня характеристика сутності розвитку і його конституційних ознак, плідна ідея саморуху та розкриття ученим виникнення і перебігу «саморуху особистості, що розвивається», а також висунута ідея керування особистістю власним психічним розвитком - це непересічне бачення Г. С. Костюком психологічного змісту розвитку - імпліцитно містить архітектоніку становлення ефективної особистості. Розуміння вченим глибинних процесів психічного розвитку і здатність до розкриття сутнісних змістовних ознак становлення ефективної та успішної особистості є унікальним надбанням вітчизняної психологічної думки.

Принципово важливим для розуміння становлення ефективної особистості є висунута Г. С. Костюком ідея 
стадійності розвитку, що розкриває перебіг і динаміку особистісного становлення в онтогенетичному просторі. Кожна стадія є констеляцією в єдності ознак таких площин, як «Я - фізичне», «Я - психічна діяльність», «Я особистість» $\mathrm{i}$ «Я - середовище». Прикметно, що учений вирізняє також і особливості зв'язків, а саме - «внутрішні зв'язки» $\mathrm{i}$ «взаємозв'язки». Генералізованою ознакою стадійності розвитку є незворотний характер послідовності стадій, підгрунтям яких є безперервний ланцюжок органічного зв'язку попередньої стадії з наступною. Водночас важливою є думка про те, що кожна з них має особливості мотиваційної, операційної та змістової сторін психічної діяльності, що утворюють структурну організацію кожної стадії. Виходячи з цих теоретико-методологічних засад, необхідно припустити, що розвиток ефективної особистості має теж чітко стадіальний характер, властивий кожному етапу онтогенезу як зі своєрідною констеляцією змістовних ознак, так і з особливою структурно-динамічною їх організацією на тому чи іншому етапі онтогенетичного становлення ефективної особистості.

Важливим внеском Г. С. Костюка у проблему становлення ефективної особистості є аналіз рушійних сил психічного розвитку. Рушійною силою переходів особистості з одного ступеня розвитку до іншого, з нижчого до вищого $\epsilon$, на його думку, внутрішні суперечності: «Особистість розвивається у зв'язку з внутрішніми протиріччями, які виникають у її житті» (Костюк, 1989: 123). Учений дає психологічний аналіз різноманітної палітри основних внутрішніх суперечностей, що притаманні різним етапам індивідуального розвитку особистості та є джерелом їі ефективності / неефективності.

Концептуально важливою для розуміння особистісної ефективності є ключова площина розгляду Г. С. Костюком сутності психічного розвитку в проекції його детермінації. Учений значну увагу приділяє розкриттю ролі середовища 
детермінації психічного розвитку індивіда, аналізуючи природне, предметне та суспільне середовище.

Співставний аналіз поглядів Г. С. Костюка у його теорії психічного розвитку індивіда на детермінацію, на роль зовнішніх і внутрішніх умов його розвитку показує, наскільки була вагомою антиципація ученим ідей, висловлених через десятиліття А. Бандурою.

Аналіз наукової спадщини Г. С. Костюка переконливо свідчить про інноваційність наукового бачення проблеми особистісної ефективності, яку він уперше репрезентував у розгорнутій доповіді «Про роль спадковості, середовища і виховання у психічному розвитку дитини» на республіканській науковій конференції з педагогіки і психології (29 січня - 4 лютого 1940 р. в м. Києві) (Костюк, 1941). Розробку цієї проблеми Г. С. Костюк не полишав упродовж усього творчого життя, розкриваючи їі у концептуальному полі не лише педагогічної та вікової психології, але й загальної психології (Костюк, 1989). Означення сенсотвірних точок перетину концептуальних парадигм А. Бандури і Г. С. Костюка має стати предметом спеціального аналізу.

Перейдемо до розгляду результатів експериментального дослідження становлення самоефективності у просторі самодетермінації особистості. Завдання дослідження полягало у розкритті взаємозв'язків, що лежать у підгрунті становлення особистості як самодетермінованого суб’єкта у дихотомічній системі «самоефективність - самодетермінація» .

У результаті проведеного експериментального дослідження були встановлені взаємозв'язки в опозиції самоефективності як моно-різновиду, що входить як органічна складова до сукупності полі-детермінант системи самодетермінації у таких площинах. Перша - передбачала аналіз самоефективності у полі смисложиттєвих орієнтацій особистості, що складають підгрунтя образу «Я» (тест «Смисложиттєві орієнтації» Дж. Крамбо та Л. Махоліка) (Леонтьєв, 2000) (табл. 1). 
Таблиия 1

Взаємозв' язок самоефективності та смисложиттєвих орієнтацій особистості

\begin{tabular}{|c|c|c|c|c|c|c|}
\hline $\begin{array}{c}\text { Показ- } \\
\text { ники }\end{array}$ & $\begin{array}{c}\text { Результа- } \\
\text { тивність } \\
\text { життя }\end{array}$ & $\begin{array}{c}\text { Осмис- } \\
\text { женість }\end{array}$ & $\begin{array}{c}\text { Цілі } \\
\text { життя }\end{array}$ & $\begin{array}{c}\text { Процес } \\
\text { життя }\end{array}$ & $\begin{array}{c}\text { Локус } \\
\text { контро- }\end{array}$ & $\begin{array}{c}\text { Локус } \\
\text { контролю } \\
\text { - життя }\end{array}$ \\
\hline $\begin{array}{l}\text { Самоефек- } \\
\text { тивність }\end{array}$ & $0,402 * *$ & $0,320 *$ & 0,211 & 0,207 & 0,252 & 0,233 \\
\hline
\end{tabular}

Примітка. ** - кореляція значуща на рівні 0,01;

* - кореляція значуща на рівні 0,05 .

Отримані експериментальні дані показали, що самоефективність входить до сенсового життєвого простору особистості, про що свідчить щільність зв'язку на рівні 0,005 із загальним показником осмисленості життя. Найбільш детермінантну роль відіграє така смислова орієнтація - результативність життя індивіда як задоволеність його самореалізацією, причому зв'язок між ними є на рівні 0,001. Дві наступні смислові орієнтації, що характеризують наявність чи відсутність цілей у житті, а також процес життя - інтерес і емоційну його насиченість, хоч мають наявні зв'язки в системі самодетермінації, але не здійснюють значущого впливу в детермінантних взаємозв'язках із самоефективністю.

Наголосимо, що і регулятивна сфера, репрезентована двома сферами локусу контролю - «локус контролю - Я» (Я - господар життя) i «локус контролю - життя» (керованість життям), має наявні зв'язки в системі самодетермінації; водночас вони теж не здійснюють статистично значущого детермінантного впливу у взаємозв'язках із самоефективністю. Цьому можна знайти пояснення в тому, що смисложиттєві орієнтації в регулятивній сфері, можливо, більшою мірою віддзеркалюють систему «Я - Я», а не систему «Я - діяльність», у якій сконцентрована діяльнісна самоефективність. 
Наступна площина аналізу - простеження взаємозв'язків самоефективності зі сферою самодетермінації особистості. 3 цією метою у дослідженні було застосовано тест «Шкала самодетермінації» К. Шелтона (Осін, 2007).

Аналіз кореляційних зв'язків свідчить про взаємозалежність самоефективності й такої шкали самодетермінації, як автономія, що має статистичну значущість на рівні 0,005. Отримані експериментальні дані показали, що психологічний зміст автономії як здатності особистості до відповідальності за перебіг власного життя й ступінь упевненості у його ефективному здійсненні має у своєму підгрунті взаємозалежні, статистично значущі зв'язки із самоефективністю. Водночас аналіз результатів за шкалою самовираження свідчить лише про наявність зв'язків (що не мають статистичної значущості) між самоефективністю і переживанням особистістю самототожності, переживанням нею самовираження (табл. 2).

Таблиия 2

Взаємозв'язок самоефективності та самодетермінації особистості

\begin{tabular}{|c|c|c|}
\hline Показники & Автономія & Самовираження \\
\hline Самоефективність & $0,356 * \%$ & 0,180 \\
\hline
\end{tabular}

Примітка. ** - кореляція значуща на рівні 0,01 .

Третя площина аналізу передбачала з'ясування взаємозв'язків самоефективності з такою особистісною сферою, як життєстійкість. Ця особистісна змінна характеризує міру здатності людини до продуктивної, успішної діяльності всупереч впливу стресогенних чинників, зберігаючи при цьому внутрішню збалансованість. Із цією метою було застосовано тест життєстійкості С. Мадді (Леонтьєв \& Розсказова, 2006).

Зазначимо, що опозиція «самоефективність - життестійкість» має високий ступінь взаємозалежності та $\epsilon$ 
свідченням органічного зв'язку між цими особистісними сферами у системі детермінації. Так, із чотирьох шкал життєстійкості три з них мають взаємозалежні зв'язки на рівні значущості 0,001. Це - такі сенсові шкали, як включеність, контроль і загальна життєстійкість (табл. 3).

Таблиия 3

Взаємозв' язок самоефективності та життєстійкості

\begin{tabular}{|l|c|c|c|c|}
\hline Показники & Контроль & Включеність & $\begin{array}{c}\text { Прийняття } \\
\text { ризику }\end{array}$ & $\begin{array}{c}\text { Загальна } \\
\text { життстійкість }\end{array}$ \\
\hline $\begin{array}{l}\text { Самоефек- } \\
\text { тивність }\end{array}$ & $0,411 * *$ & $0,396 * *$ & 0,240 & $0,398 * *$ \\
\hline
\end{tabular}

Примітка. ** - кореляція значуща на рівні $0,01$.

Тобто, такі показники, як включеність у діяльність, отримання задоволення від неї, контроль, що «знімає» в особистості відчуття власної безпорадності, а також загальна життєстійкість як синтез цих змінних, забезпечують наявність стійких і значущих взаємозв'язків із самоефективністю особистості. Така змінна життєстійкості, як прийняття ризику, хоча й має наявні взаємозв'язки із самоефективністю, однак без статистично значущої кореляції.

Четверта площина аналізу передбачала з'ясування взаємозв'язків самоефективності 3 такою особистісною сферою, як самоставлення. 3 цією метою було застосовано тест-опитувальник «Самоставлення особистості» В. В. Століна та С. Р. Пантілєєва (Столін \& Пантілєєв, 1988).

Отримані експериментальні дані дозволили з'ясувати особливості взаємозв' язку показників самоефективності та самоставлення особистості (табл. 4). В ієрархічній структурі самоставлення зафіксовано значущий взаємозв'язок самоефективності та першого рівня самоставлення особистості - глобального самоставлення. Це свідчить про те, що у просторі самодетермінації самоставлення є органічно включеним базальним чинником, який має взаємообумов- 
лений вектор впливу в дихотомічній системі «самоефективність - самоставлення».

Таблиця 4

Взаємозв’язок самоефективності та самоставлення особистості

\begin{tabular}{|c|c|c|c|c|c|c|c|c|c|c|c|c|}
\hline \multirow[b]{2}{*}{ Показники } & \multirow[b]{2}{*}{ 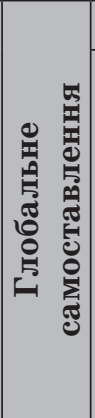 } & \multicolumn{11}{|c|}{ Диференційоване самоставлення } \\
\hline & & 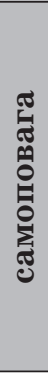 & 鵸 & 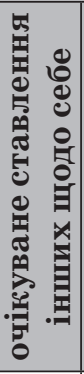 & 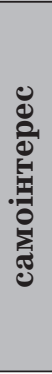 & . & 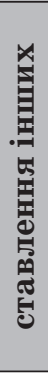 & & 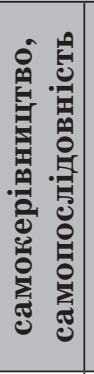 & 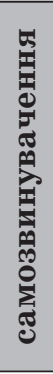 & $\begin{array}{l}0 \\
0 \\
0 \\
0 \\
0 \\
0 \\
0 \\
0 \\
0 \\
0 \\
0 \\
.:\end{array}$ & \\
\hline $\begin{array}{c}\text { Самоефек- } \\
\text { тивність }\end{array}$ & 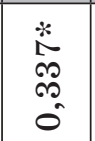 & 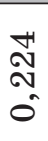 & $\frac{*}{\underset{C}{C}}$ & 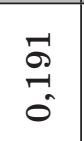 & $\begin{array}{c}\stackrel{+}{+} \\
\stackrel{+}{0}\end{array}$ & $\begin{array}{l}\stackrel{0}{0} \\
\stackrel{0}{0} \\
\text { O. }\end{array}$ & $\begin{array}{l}\infty \\
\infty \\
0 \\
0 \\
0\end{array}$ & 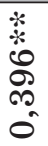 & $\begin{array}{l}\stackrel{0}{+} \\
\stackrel{1}{0}\end{array}$ & $\begin{array}{l}\text { N } \\
\text { Oे } \\
\stackrel{-}{0}\end{array}$ & 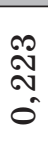 & $\frac{\stackrel{N}{+}}{\stackrel{+}{0}}$ \\
\hline
\end{tabular}

Примітка. ** - кореляція значуща на рівні 0,01 ;

* - кореляція значуща на рівні 0,05 .

Водночас на другому рівні - у макроструктурі диференційованого самоставлення значущий зв'язок простежується лише з аутосимпатією. У цьому віддзеркалюється беззаперечний домінантний статус емоційного самоприйняття особистості у взаємовпливі з їі самоефективністю. Довіра до себе, позитивна самооцінка, схвалення себе загалом як суб’єкта життєдіяльності є важливими предикторами самодетермінації особистості.

Стійкість цієї тенденції у дихотомічній системі «самоефективність - самоставлення» підтверджується даними щодо репрезентації третього рівня самоставлення - рівня конкретних (чи очікуваних) дій у ставленні до свого «Я» . Прикметно, що серед семи шкал цього рівня самоставлення лише третя шкала - самоприйняття - є високо значущою (на рівні 0,001) у взаємозв'язках із самоефективніс- 
тю. Ці дані переконливо свідчать про наявність тенденції, яка вже має характер закономірності у самодетермінації особистості. Тобто, ідентичність у ставленні до свого «Я» такої ознаки самоставлення, як самоприйняття, не лише на другому, а й на третьому рівнях свідчить про включеність самоакцептації особистості в усе поле взаємозв'язків системи «самоефективність - самоставлення» .

У контексті технологічного аспекту досліджуваної проблеми аналіз взаємозв'язків дихотомічної системи «самоефективність - самодетермінація» дав змогу окреслити модель продуктивного перебігу взаємовпливу самоефективності у просторі самодетермінації особистості (рис. 1).

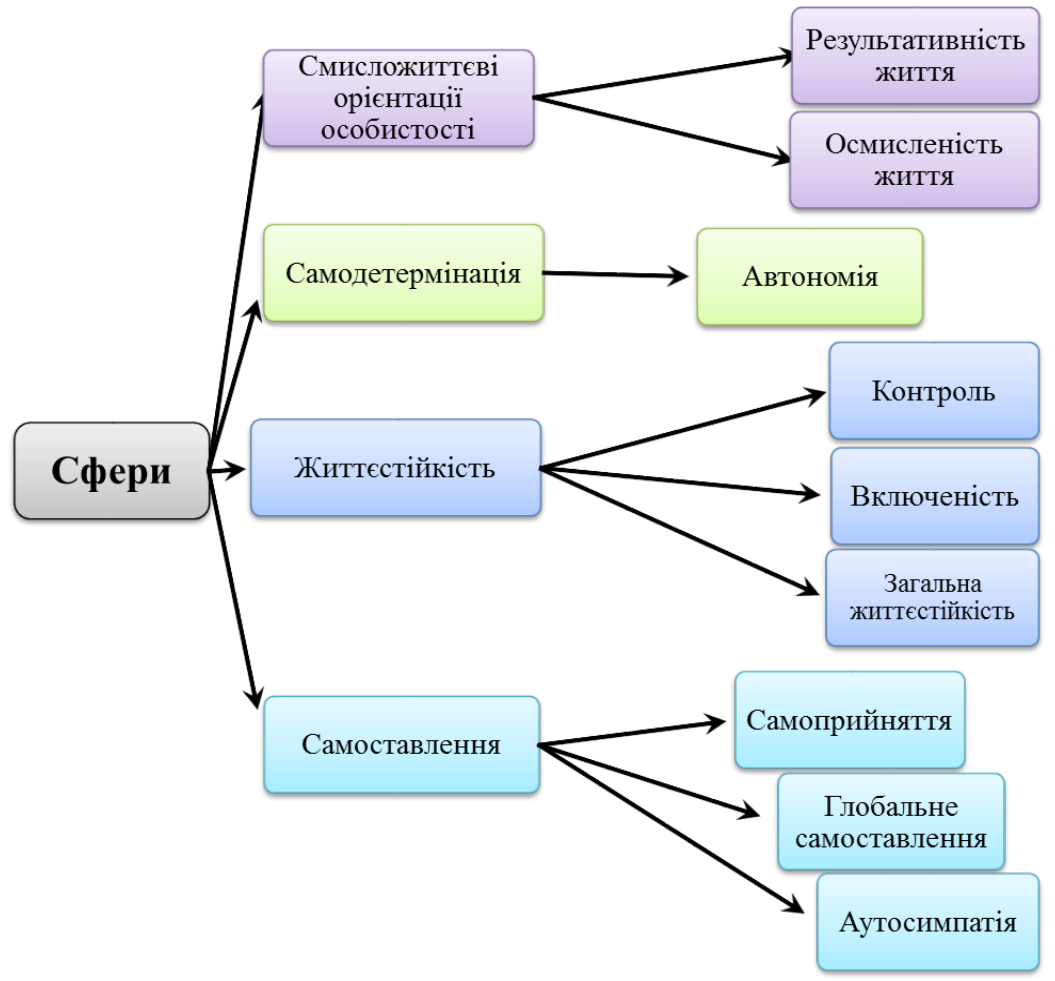

Puc. 1. Модель продуктивної самоефективності

у просторі самодетермінації 
У концептуальному полі серед чинників продуктивного становлення взаємозв'язків у системі «самоефективність - самодетермінація» чітко виокремлюються такі чотири сфери: смисложиттєві орієнтації особистості, самодетермінація, життєстійкість і самоставлення особистості. У кожній із цих сфер зафіксовані домінуючі ознаки, що є стрижневими в ефективному перебігу взаємозв' язків. Найвагомішими за впливом є такі ознаки (рівень значущості 0,001): у сфрері смисложиттєвих орієнтацій особистості результативність життя особистості; у сфері життєстійкості - контроль, включеність і загальна життєстійкість особистості; у сфері самоставлення - самоприйняття особистістю самої себе.

Важливу роль у самодетермінантному просторі відіграють (на рівні значущості 0,005) взаємозв'язки між самоефективністю і самодетермінацією у зазначених чотирьох сферах за такими ознаками: у сфері смисложиттєвих орієнтацій - осмисленість життя, у сфері самодетермінації автономія; у сфері життєстійкості - включеність, у сфері самоставлення - аутосимпатія. Урахування особливостей включення самоефективності у самодетермінантний простір відкриває нові горизонти бачення шляхів продуктивного особистісного розвитку та саморозвитку.

\section{Висновки}

Проблема особистісної ефективності, значущість її теоретико-експериментального вивчення має статус магістральної для наукових розвідок XXI ст. Концептуальна парадигма самоефективності / особистісної ефективності А. Бандури у контексті загальної та соціальної психології вимагає синергійного бачення з урахуванням непересічних наукових надбань Г. С. Костюка, його концептуального розуміння проблеми ефективності й особистісної ефективності у загальній, педагогічній і віковій психології. Зроблено висновок, що вчений уперше самобутньо ініціював у педагогічній і віковій психології (як у вітчизняній, так 
і зарубіжній) проблему ефективності особистості у системному вимірі.

Здійснене теоретико-експериментальне дослідження дало змогу простежити включення самоефективності до системи самодетермінації особистості. Установлено, що самоефективність як детермінанта має дихотомічний характер впливу на перебіг процесу самодетермінації особистості, стрижневою ознакою якого є дивергентна / конвергентна проекція включення цієї детермінанти в особистісний простір. Результати проведеного експерименту дали змогу охарактеризувати самоефективність у полі смисложиттєвих орієнтацій особистості; простежити взаємозв'язки самоефективності зі сферою самодетермінації особистості; з'ясувати взаємозв'язки в опозиції «самоефективність життєстійкість»; установити взаємозв'язки самоефективності та самоставлення; розкрити тенденції взаємозв'язків у дихотомічній системі «самоефективність - самодетермінація»; виокремити домінантні ознаки, що є стрижневими в ефективному становленні взаємозв'язків системи «самоефективність - самодетермінація», а також окреслити модель продуктивного перебігу самоефективності у просторі самодетермінації особистості.

Перспективи подальшого дослідження полягають у з'ясуванні характеру взаємозв'язків у системі «самоефективність - самодетермінація» на різних етапах онто- й актуалґенези становлення ефективної особистості.

\section{Література}

Бандура А. Теория социального научения. Санкт-Петербург : Евразия, 2000. $320 \mathrm{c}$.

Бондарчук О. І. Організаційно-професійні особливості самоефективності керівників освітніх організацій. Проблеми сучасної психологї: Збірник наукових праць Кам'янець-Подільського національного університету імені Івана Огієнка, Інституту психології ілені Г. С. Костюка НАПН України. Кам'янець-Подільський : Аксіома, 2015. Вип. 27. С. 57-69.

Володарська Н. Д. Можливості впливу життєвих перспектив на активізацію самодетермінації розвитку особистості у кризових ситу- 
аціях. Науковий вісник Херсонського державного університету. Серія «Психологічні науки». Херсон, 2018. Вип. 4. С. 80-88.

Дригус М. Т. Концепція психічного розвитку Г. С. Костюка у парадигмі особистісної ефективності. Ажтуальні проблели психологї̈: Збірник наукових праць Інституту психологї ілені Г. С. Костюка НАПН України. Том IX: Загальна психологія. Історична психологія. Етнічна психологія. Київ : Талком, 2016. Вип. 9. С. 187-194.

Костюк Г. С. Навчально-виховний процес і психічний розвиток особистості. Київ : Радянська школа, 1989. 608 с.

Костюк Г. С. Про роль спадковості, середовища і виховання в психічному розвитку дитини. Праці респ. наук. конф. з педагогіки $і$ психологї. Т. ІІ. Психологія. Київ : Радянська школа, 1941. С. 3-45.

Леонтьев Д. А. Тест смысложизненных ориентаций (СЖО). 2-е изд. Москва : Смысл, 2000. 18 с.

Леонтьев Д. А., Рассказова Е. И. Тест жизнестойкости. Москва : Смысл, $2006.63 \mathrm{c}$.

Мушегов О. М. Особливості самоефективності педагогічних працівників загальноосвітніх навчальних закладів. Організаційна психологія. Еконолічна психологія. Науковий журнал. Київ : Логос, 2016. № 2-3 (5-6). С. 97-103.

Локальні системи управління якістю: світовий досвід та українські практики побудови / В. І. Терещук, Т. В. Фініков та ін.; за ред. Т. В. Фінікова, В. І. Терещук. Київ : Таксон, 2018. 316 с.

Максименко С. Д., Сердюк Л. З. Психологічна основа самореалізації особистості: структура і функція. Актуальні проблели психологї: Збірник наукових праць Інституту психологї ілені Г. С. Костюка НАПН Украӥни. Том IX: Загальна психологія. Історична психологія. Етнічна психологія. Київ : Талком, 2016. Вип. 9. С. 6-13.

Осин Е. Н. Чувство связности как показатель психологического здоровья и его диагностика. Психологическая диагностика. 2007. № 3. С. 22-40.

Пенькова О. І. Ціннісні аспекти самореалізації особистості. Актуальні проблели психологї: Збірник наукових праць Інституту психології ілені Г. С. Костюка НАПН України. Том VI. Психологія обдарованості. Київ - Житомир : Видавництво ЖЖДУ імені І. Франка, 2018. Вип. 14. С. 201-207.

Ребер А. Большой толковый психологический словарь. Москва : Вече, АСТ, 2000. Т. 2 (П-Я). 559 с.

Сердюк Л. 3. Психологічні фактори самодетермінації особистості. Актуальні проблели психологї: Збірник наукових праць Інституту психологї ілені Г. С. Костюка НАПН Украӥни. Т. V. Психофізіологія. Психологія праці. Експериментальна психологія. 2018. Вип. 18. С. 311-317. 
Столин В. В., Пантилеев С. Р. Опросник самоотношения. Практикул по психодиагностике: психодиагностические латериаль. Москва : Издательство Московского университета, 1988. С. 123-130.

Турбан В. В. Проблема самодетермінації особистості в часі. Вісник Національного університету оборони України. 2018. № 2 (50). С. 164171.

Фалькова I. М. До проблеми розвитку творчої самоефективності особистості студентської молоді у контексті ідей Г. С. Костюка. Психологічні координати розвитку особистості: реалії та перспективи: Збірник наукових матеріалів II Всеукр. наук.-практ. конф. (17 травня 2017 р., м. Полтава). Полтава : Видавець Шевченко Р. В., 2017. С. 192-194.

Чайка Г. В. Методологія дослідження особистісної автономії як ключової ознаки самодетермінації особистості. Актуальні проблели психології: Збірник наукових праць Інституту психологї̈ ілені Г. С. Костюка НАПН України. Том V: Психофізіологія. Психологія праці. Експериментальна психологія. 2017. Вип. 17. С. 133141.

Чиханцова О. А. Особливості прояву компонентів життєстійкості особистості. Актуальні проблели психологї: Збірник наукових праць Інституту психологї ілені Г. С. Костюка НАПН Украӥни. Т. VI. Психологія обдарованості. Київ - Житомир : Видавництво ЖЖДУ імені І. Франка, 2018. Вип. 14. С. 267-273.

Шварцер Р., Ерусалем М., Ромек В. Русская версия шкалы общей самоэффективности Р. Шварцера и М. Ерусалема. Иностранная психология. 1996. № 7. С. 71-76.

Яворська-Вєтрова I. В. Самоставлення та смислові життєві орієнтації студентської молоді: аналіз емпіричного дослідження. Ажтуальні проблели психологї: Збірник наукових пращь Інституту психологї ілені Г. С. Костюка НАПН України. Том IX. Загальна психологія. Історія психології. Етнічна психологія. 2018. Вип. 11. C. 243-252.

Bandura, A. (1977). Self-efficacy: toward a unifying theory of behavioral change. Psychological review, 84 (2), 191-215. Retrieved from http://dx.doi.org/10.1037/0033-295X.84.2.191.

Bandura, A. (1978). The self system in reciprocal determinism. American Psychologist, 33 (4), 344-358. Retrieved from http://dx.doi. org/10.1037/0003-066X.33.4.344.

Bandura, A. (1994). Self-efficacy. In V. S. Ramachaudran (Ed.). Encyclopedia of human behavior, 4, 71-81. New York : Academic Press.

Bandura, A. (2012). On the Functional Properties of Perceived Self-Efficacy Revisited. Journal of Management, 38 (1), 9-44. Retrieved from https://doi.org/10.1177/0149206311410606. 
Deci, E. L., \& Ryan, R. M. (2000). The «what» and «why» of goal pursuits Human needs and the self-determination of behavior. Psychological Inquiry, 11, 227-268.

Onufriieva, L. A. The theoretical and methodological analysis of «Meprofessional» image as a component of future professionals «Meconcept». S. D. Maksymenko, L. A. Onufriieva (Eds.). Problems of Modern Psychology: Collection of research papers of KamianetsPodilskyi National Ivan Ohiienko University, G.S. Kostiuk Institute of Psychology of the National Academy of Educational Sciences of Ukraine, 39, 195-205. Retrieved from https://doi:10.32626/22276246.2018-39.195-205.

Stajkovic, A. D., Bandura, A., Locke, L. A., \& Lee, D. (2018). Test of three conceptual models of influence of the big five traits and self-efficacy on academic performance: A meta-analytic path-analysis. Personality and individual differences, 120, 238-245. Retrieved from https:// doi: 10.1016/j.paid.2017.08.014.

\section{References}

Bandura, A. (2000). Teorija sotsial'nogo nauchenija [Social Learning Theory ]. Sankt-Peterburg : Evrazija [in Russian].

Bondarchuk, O. I. (2015). Orhanizatsiino-profesiini osoblyvosti samoefektyvnosti kerivnykiv osvitnikh orhanizatsii [The organizational and professional features of self-efficacy of managers of educational organizations]. S. D. Maksymenko, L. A. Onufriieva (Eds.). Problemy suchasnoi psykholohii - Problems of Modern Psychology: Collection of research papers of Kamianets-Podilskyi Ivan Ohienko National University, G. S. Kostiuk Institute of Psychology at the National Academy of Educational Sciences of Ukraine, 27, 57-69. KamianetsPodilskyi : Aksioma [in Ukrainian].

Volodarska, N. D. (2018). Mozhlyvosti vplyvu zhyttievykh perspektyv na aktyvizatsiiu samodeterminatsii rozvytku osobystosti u kryzovykh sytuatsiiakh [Possibilities of life perspectives impact on activation of personality self-development in crisis situations]. Naukovyi visnyk Khersonskoho derzhavnoho universytetu. Seriia «Psykholohichni nauky» - Scientific Newsletter of Kherson State University. Series «Psychological Sciences», 4, 80-88). Kherson [in Ukrainian].

Dryhus, M. T. (2016). Kontseptsiia psykhichnoho rozvytku H. S. Kostiuka u paradyhmi osobystisnoi efektyvnosti [The concept of psychic development proposed by G.S. Kostiuk within the personal efficiency paradigm]. Aktualni problemy psykholohii - Actual Problems of Psychology: Collection of scientific works of G.S. Kostiuk Institute of Psychology of the National Academy of Educational Sciences of Ukraine. 
Vol. IX: General Psychology. History of psychology. Ethnic psychology, 9, 187-194. Kyiv : Talkom [in Ukrainian].

Kostiuk, H. S. (1989). Navchalno-vykhovnyi protses i psykhichnyi rozvytok osobystosti [Educational process and mental development]. L. M. Prokoliienko (Ed.). Kyiv : Radianska shkola [in Ukrainian].

Kostiuk, H. S. (1941). Pro rol spadkovosti, seredovyshcha i vykhovannia v psykhichnomu rozvytku dytyny [On the role of heredity, environment and education in a child's mental development]. Pratsi resp. nauk. konf. $z$ pedahohiky i psykholohii-Proceedings of the republic scientific conference on pedagogy and psychology. (Vol. II. Psychology), (pp. 3-45). Kyiv : Radianska shkola [in Ukrainian].

Leont'ev, D. A. (2000). Test smyslozhiznennyh orientatsij (SZhO) [Lifemeaningful orientation test]. Moskva : Smysl [in Russian].

Leont'ev, D. A., \& Rasskazova, E. I. (2006). Test zhiznestojkosti [Life-hardiness test]. Moskva : Smysl [in Russian].

Mushehov, O. M. (2016). Osoblyvosti samoefektyvnosti pedahohichnykh pratsivnykiv zahalnoosvitnikh navchalnykh zakladiv [The Peculiarities of Self-Efficiency of Teachers of General Education Institutions]. S. D. Maksymenko, L. M. Karamushka (Eds.). Orhanizatsiina psykholohiia. Ekonomichna psykholohiia. Naukovyi zhurnal - Organizational psychology. Economic psychology. Scientific journal, 2-3 (5-6), 97-103 [in Ukrainian].

Finikov, T. V., \& Tereshchuk, V. I. (Eds.) (2018). Lokalni systemy upravlinnia yakistiu: svitovyi dosvid ta ukrainski praktyky pobudovy [Local Quality Management Systems: Worldwide Experience and Ukrainian Practices for their Construction]. Kyiv : Takson [in Ukrainian].

Maksymenko, S. D., \& Serdiuk, L. Z. (2016). Psykholohichna osnova samorealizatsii osobystosti: struktura i funktsiia [Psychological basis of personality's self-realization: structure and function]. Aktualni problemy psykholohii - Actual Problems of Psychology: Collection of scientific works of G.S. Kostiuk Institute of Psychology of the National Academy of Educational Sciences of Ukraine. Vol. IX: General Psychology. History of psychology. Ethnic psychology, 9, 6-13. Kyiv : Talkom [in Ukrainian].

Osin, E. N. (2007). Chuvstvo svyaznosti kak pokazatel' psihologicheskogo zdorov'ja i ego diagnostika [Relatedness as an indicator of psychological health and its diagnosis]. Psihologicheskaja diagnostika - Psychological diagnosis, 3, 22-40 [in Russian].

Penkova, O. I. (2018). Tsinnisni aspekty samorealizatsii osobystosti [Valuable aspects of self-realization]. Aktualni problemy psykholohii-Actual Problems of Psychology: Collection of scientific works of G.S. Kostiuk Institute of Psychology of the National Academy of Educational Sciences of Ukraine. Vol. VI. Psychology of giftedness, 14, 201-207. 
Kyiv - Zhytomyr : Vydavnytstvo ZhDU imeni I. Franka [in Ukrainian].

Reber, A. (2000). Bol'shoj tolkovyj psihologicheskij slovar' [Large explanatory psychological dictionary]. Moskva : Veche, AST [in Russian].

Serdiuk, L. Z. (2018). Psykholohichni faktory samodeterminatsii osobystosti [Psychological factors of self-determination]. Aktualni problemy psykholohii - Actual Problems of Psychology: Collection of Scientific Works of G.S. Kostiuk Institute of Psychology of the National Academy of Educational Sciences of Ukraine. Vol. V. Psychophysiology. Psychology of labor. Experimental psychology, 18, 311-317 [in Ukrainian].

Stolin, V. V., \& Pantileev, S. R. (1988). Oprosnik samootnoshenija [Selfattitude questionnaire]. Praktikum po psihodiagnostike: psihodiagnosticheskie materialy - Practice on psychodiagnostics: psychodiagnostic materials, (pp. 123-130). Moskva : Izdatel'stvo Moskovskogo universiteta [in Russian].

Turban, V. V. (2018). Problema samodeterminatsii osobystosti v chasi [The problem of personal self-determination in time]. Visnyk Natsionalnoho universytetu oborony Ukrainy - Bulletin of the National Defence University of Ukraine, 2(50), 164-171. Kyiv : NUOU [in Ukrainian].

Falkova, I. M. (2017). Do problemy rozvytku tvorchoi samoefektyvnosti osobystosti studentskoi molodi u konteksti idei H. S. Kostiuka [To the problem of the development of the creative self-efficiency of a student's youth in the context of the ideas of G. S. Kostiuk]. Psykholohichni koordynaty rozvytku osobystosti: realii ta perspektyvy Psychological Coordinates of Personality Development: Realities and Prospects: Collection of Scientific Materials of the 2nd All-Ukrainian Scientific and Practical Conference, (pp. 192-194). Poltava : Vydavets Shevchenko R. V. [in Ukrainian].

Chaika, H. V. (2017). Metodolohiia doslidzhennia osobystisnoi avtonomii yak kliuchovoi oznaky samodeterminatsii osobystosti [Methodology of research on personal autonomy as a key feature of self-determination]. Aktualni problemy psykholohii-Actual Problems of Psychology: Collection of Scientific Works of G. S. Kostiuk Institute of Psychology of the National Academy of Educational Sciences of Ukraine. Vol. V. Psychophysiology. Psychology of labor. Experimental psychology, 17, 133-141 [in Ukrainian].

Chykhantsova, O. A. (2018). Osoblyvosti proiavu komponentiv zhyttiestiikosti osobystosti [Features of manifestations of the psychological hardiness components]. Aktualni problemy psykholohii-Actual Problems of Psychology: Collection of Scientific Works of G.S. Kostiuk Institute of Psychology of the National Academy of Educational Sciences of Ukraine. Vol.VI. Psychology of giftedness, 14, 267-273. Kyiv - Zhytomyr : Vydavnytstvo ZhDU imeni I. Franka [in Ukrainian]. 
Shvartser, R., Erusalem, M., \& Romek, V. (1996). Russkaja versija shkaly obshchej samojeffektivnosti R. Shvartsera i M. Erusalema [Russian version of the general self-efficacy scale of R. Schwarzer and M. Jerusalem]. Inostrannaja psihologija - Foreign psychology, 7, 71-76 [in Russian].

Yavorska-Vietrova, I. V. (2018). Samostavlennia ta smyslovi zhyttievi oriientatsii studentskoi molodi: analiz empirychnoho doslidzhennia [Self-attitude and meaningful life orientations of students: analysis of the empirical research]. Aktualni problemy psykholohii - Actual Problems of Psychology: Collection of Scientific Works of G. S. Kostiuk Institute of Psychology of the National Academy of Educational Sciences of Ukraine. Vol. IX: General Psychology. History of psychology. Ethnic psychology, 11, 243-252 [in Ukrainian].

Bandura, A. (1977). Self-efficacy: toward a unifying theory of behavioral change. Psychological review, 84 (2), 191-215. Retrieved from http://dx.doi.org/10.1037/0033-295X.84.2.191.

Bandura, A. (1978). The self system in reciprocal determinism. American Psychologist, 33 (4), 344-358. Retrieved from http://dx.doi. org/10.1037/0003-066X.33.4.344.

Bandura, A. (1994). Self-efficacy. In V. S. Ramachaudran (Ed.). Encyclopedia of human behavior, 4, 71-81. New York : Academic Press.

Bandura, A. (2012). On the Functional Properties of Perceived Self-Efficacy Revisited. Journal of Management, 38 (1), 9-44. Retrieved from https://doi.org/10.1177/0149206311410606.

Deci, E. L., \& Ryan, R. M. (2000). The "what» and «why» of goal pursuits Human needs and the self-determination of behavior. Psychological Inquiry, 11, 227-268.

Onufriieva, L. A. The theoretical and methodological analysis of «Meprofessional» image as a component of future professionals «Meconcept». S. D. Maksymenko, L. A. Onufriieva (Eds.). Problems of Modern Psychology: Collection of research papers of KamianetsPodilskyi National Ivan Ohiienko University, G.S. Kostiuk Institute of Psychology of the National Academy of Educational Sciences of Ukraine, 39, 195-205. Retrieved from https://doi:10.32626/22276246.2018-39.195-205.

Stajkovic, A. D., Bandura, A., Locke, L. A., \& Lee, D. (2018). Test of three conceptual models of influence of the big five traits and self-efficacy on academic performance: A meta-analytic path-analysis. Personality and individual differences, 120, 238-245. Retrieved from https:// doi: $10.1016 /$ j.paid.2017.08.014. 
Дригус Марія. Характеристика самоефективності у просторі самодетермінації особистості

\section{АНОТАЦІЯ}

У статті представлено результати теоретико-експериментального дослідження проблеми самоефективності у просторі самодетермінації особистості. здійснено теоретико-методологічний аналіз проблеми самоефективності у різних концептуальних підходах вітчизняної та зарубіжної психології. Розкрито концептуальну парадигму самоефективності А. Бандури у контексті реципрокного детермінізму теорії сочіального научіння. Розкрито концептуальну парадигму Г. С. Костюка щодо проблеми становлення ефективності особистості у контексті концепції психічного розвитку індивіда. Акцентовано на тому, що Г. С. Костюк уперше самобутньо ініціював, ще у 40-х рр. ХХ ст., проблему особистісної самоефективності у системному вимірі. Окреслено концептуальне підгрунтя розробки проблеми самоефективності у вітчизняній психології, а також висвітлено спектри експериментального дослідження проблеми самодетермінації особистості у сучасному вітчизняному психологічному просторі. здійснено аналіз експериментального дослідження взаємозв'язків у системі “самоефективність самодетермінація» особистості. Виокремлено сфери - смисложиттєві орієнтації, самодетермінація, життестійкість і самоставлення особистості в концептуальному просторі самодетермінації особистості. Подано характеристику самоефективності у полі смисложиттєвих орієнтацій особистості й простежено взаємозв'язки самоефективності зі сферою самодетермінації особистості; з'ясовано взаємозв'язки в опозиції "самоефективність - життєстійкість»; установлено взаємозв'язки самоефективності та самоставлення. Установлено тенденції взаємозв'язків у дихотомічній системі «самоефективність - самодетермінація». Виокремлено домінантні ознаки, що є стрижневими в ефективному становленні взаємозв'язків системи «самоефективність - самодетермінація». Окреслено модель продуктивного перебігу самоефективності у просторі самодетермінації ocoбистосmi.

Ключові слова: особистість, самоефективність, самодетермінація, розвиток, життєстійкість, смисложиттєві орієнтації, самоставлення. 
Дригус Мария. Характеристика самоэффективности в пространстве самодетерминации личности

\section{АННОТАЦИЯ}

В статье представлены результаты теоретико-экспериментального исследования проблемы самоэффективности в пространстве самодетерминации личности. Осуществлен теоретико-методологический анализ проблемы самоэфрективности в разных концептуальных подходах отечественной и зарубежной психологии. Раскрыта концептуальная парадигма самоэффективности А. Бандуры в контексте реципрокного детерминизма теории социального научения. Раскрыта концептуальная парадигма Г. С. Костюка проблемы становления эффективности личности в контексте концепции психического развития индивида. Акцентировано на том, что Г. С. Костюк впервые самобытно инициировал еще в 40-х г2. ХХ в. проблему личностной самоэффективности в системном измерении. Очерчено концептуальное основание разработки проблемы самоэффективности в отечественной психологии, а также освещены спектры экспериментального исследования проблемы самодетерминации личности в современном отечественном психологическом пространстве. Осуществлен анализ экспериментального исследования взаимосвязей в системе "самоэфрективность - самодетерминация" личности. Выделены сферы смысложизненные ориентации, самодетерминация, жизнестойкость и самоотношение в концептуальном пространстве самодетерминации личности. Представлена характеристика самоэффрективности в поле смысложизненных ориентаций личности; прослежена взаимосвязь самоэффективности и сферы самодетерминации личности; выяснена взаимосвязь в оппозиции «самоэффективность - жизнестойкость", а также взаимосвязь самоэффективности и самоотношения. Установлены тенденции взаимосвязи в дихотомической системе "самоэффективность - самодетерминация». Выделены доминантные признаки, которые являются стержневыми в эффективном становлении взаимосвязи системы "самоэффрективность - самодетерминация». Создана модель продуктивной самоэффективности в пространстве самодетерминации личности.

Ключевые слова: личность, самоэффективность, самодетерминация, развитие, жизнестойкость, смысложизненные ориентации, самоотношение. 